\title{
Battle over censorship
}

\section{San Francisco}

IN an action that may cause a fundamental change in the way government research contracts are written in the United States, Stanford University has filed a lawsuit to prevent federal government control of publication of research results. Stanford alleges that the National Heart, Lung, and Blood Institute (NHLBI), a part of the National Institutes of Health (NIH), violated the University's rights to free speech granted by the First Amendment when it withdrew an offer for a research contract.

Stanford had refused to sign the agreement if it contained the stipulation that the government had the authority to censor publication of the research results. In the suit filed on 24 October, the University is seeking to have the $\$ 1.4$ million contract returned to Stanford, and to stop the Department of Health and Human Services (DHHS), which oversees NIH research contracts, from demanding such an agreement in future contracts with any institution. The suit, filed on behalf of Stanford's Board of Trustees, named as defendants DHHS; NHLBI; Louis Sullivan, secretary of DHHS; and Claude Lenfant, director of NHLBI.

The 'Confidentiality of Information Clause', a DHHS regulation which NHLBI insisted be included in the contract, violates Stanford's policy of openness in research, which was adopted in 1969 , by stating that research results could not be published if the agency posed any written objections. The university's suit maintains that when NHLBI withdrew the contract offer on 31 August for the sole reason that Stanford objected to the clause, the "defendants punished Stanford for asserting its constitutional right to free speech". Six days after the contract was withdrawn from Stanford, it was awarded to St Louis University Medical Center.

The dispute arose over a contract offered by NHLBI to Stanford for clinical trials in patients of a permanently implantable heart pump known as the Left Ventricular Assist System (LVAS), to be conducted by Philip Oyer, a professor of cardiovascular surgery in the Stanford University School of Medicine. Oyer has worked on development of the device for almost 20 years. Patients awaiting heart transplants have been successfully sustained at Stanford and elsewhere by a temporary version of the LVAS, manufactured by Novacor, a division of Baxter Healthcare Corp. The long-term version is to be tested for patients with endstage heart failure for whom an appropriate donor cannot be located.

Most American research universities have policies similar to Stanford's rules on

openness in research, according to Robert Rosenzweig, president of the American Association of Universities. Stanford's policy guidelines on secrecy in research require that all interested parties have freedom of access to research data, processes and results. It also states that Stanford will not enter into any research programme that permits an outside sponsor to restrict publication.

According to Stanford's complaint, the DHHS regulation requires the confidentiality of information clause be included in contracts when personal privacy or proprietary information must be guarded, or when public disclosure of preliminary unvalidated findings "have the possibility SCIENCE IN GERMANY

\section{Clean slate for academy}

\section{Munich}

IN an act signalling that science in eastern Germany requires a clean break with the past, the West Berlin parliament agreed on 26 October that the learned society of the East German Academy of Sciences should be dissolved if it failed to reform itself speedily and completely. The 70 research institutes that formed the backbone of the academy have already been removed and attached to the new East German Länder while their future is being decided.

The society includes not only local and foreign members chosen for their scientific achievement but also institute directors who received their positions through accommodation with the Commuist regime. Many have managed to retain their posts as well as their membership in the society.

The decree was introduced into the West Berlin parliament at the urging of enraged members of the East Berlin parliament, some of whom are researchers who suffered at the hands of the Communists. Hilde Schramm, a member of the left-wing Alternative Liste party that co-sponsored the bill. says that West Berlin parliamentarians wanted to move on to other business, but the East Berliners insisted that the decree be passed before the parliament adjourned in late October. The West Berlin decree calls upon the city government to disband the learned society of the academy with all of its members but at the same time to "preserve the tradition-rich body" for a new set of members. The society traces its history back to 1700 , when it was founded under the guidance of Gottfried von Leibnitz as the 'Brandenburg Society of Sciences', also known as the Prussian Academy. The society will probably be recast as an 'Academy of Sciences in Berlin and of adverse effects on the public or the Federal agency". After the contract was awarded to St Louis University, Stanford officials filed a protest with the General Accounting Office (GAO). That office dismissed the protest, stating the First Amendment challenge issued by Stanford was a matter for the courts.

At issue in this case is the question of whether First Amendment rights can be contracted away, according to Robert Charrow, former principal deputy counsel general for DHHS. He notes that in cases of national security these rights can be removed by a contract. Thus, while the parties agree that research data must be handled responsibly, Stanford's challenge may determine whether such biomedical research can be classified by a government rule.

Elizabeth Schaefer

Brandenburg'. Nevertheless, maintaining the tradition while expelling all the members will be a difficult goal.

Academy President Horst Klinkmann, with the help of a 20-member committee, is frantically trying to prepare a new statute for the society with revised criteria for membership in time for consideration by the government of a reunified Berlin due to be elected on 2 December. Earlier, Klinkmann had tried without success to persuade all current members of the learned society to accept "non-active membership' while new members were installed. But the plan, which would probably not have survived the scrutiny of Western academies, failed when a number of hard-liners refused to give up their memberships.

One organization that will have a strong say in the structure of the new society is the 'Conference of Academies of Arts and Science's in the Federal Republic of Germany', based in Mainz, which has five member academies in the western Länder. The chairman of the conference, Gotthard Schettler of Heidelberg, says that the Berlin society must conform to the standards of political and scientific autonomy set by the other members if it is to be accepted and funded, as the other academies are, by the Bund-Länder Konferenz, a body which is funded equally by the federal government and the Länder. Schettler says that the majority of the members of the learned society are "scientifically not qualified" and among the ones who are qualified, many "are politically highly suspect". Therefore, he recommends that the members who are nominated for re-election to the reformed academy submit to an outside review. "If they want to keep the old Kader (party members), then we won't play along", says Schettler.

Steven Dickman 